Check for updates

Cite this: RSC Adv., 2018, 8, 9670

\title{
Pyridazine-bridged cationic diiridium complexes as potential dual-mode bioimaging probes $\uparrow$
}

\author{
Ruth E. Daniels,,$^{\mathrm{a}}$ Luke K. McKenzie,,$^{\mathrm{bc}}$ Jonathan R. Shewring, (DD b Julia A. Weinstein, ${ }^{\mathrm{b}}$
} Valery N. Kozhevnikov (D) ${ }^{* a}$ and Helen E. Bryant (D)*c

A novel diiridium complex $\left[\left(N^{\wedge} C^{\wedge} N\right)_{2} \operatorname{Ir}\left(\right.\right.$ bis $\left.\left.-N^{\wedge} C\right) \operatorname{lr}\left(N^{\wedge} C^{\wedge} N\right)_{2} C l\right] P F_{6}\left(N^{\wedge} C^{\wedge} N=2\right.$-[3-tert-butyl-5-(pyridin-2$\mathrm{yl}$ )phenyl]pyridine; bis- $\mathrm{N}^{\wedge} \mathrm{C}=3,6$-bis(4-tert-butylphenyl)pyridazine) was designed, synthesised and characterised. The key feature of the complex is the bridging pyridazine ligand which brings two cyclometallated Ir(II) metal centres close together so that $\mathrm{Cl}$ also acts as a bridging ligand leading to a cationic complex. The ionic nature of the complex offers a possibility of improving solubility in water. The complex displays broad emission in the red region $\left(\lambda_{\mathrm{em}}=520-720 \mathrm{~nm}, \tau=1.89 \mu \mathrm{s}, \Phi_{\mathrm{em}}=62 \%\right.$ in degassed acetonitrile). Cellular assays by multiphoton $\left(\lambda_{\mathrm{ex}}=800 \mathrm{~nm}\right)$ and confocal $\left(\lambda_{\mathrm{ex}}=405 \mathrm{~nm}\right)$ microscopy demonstrate that the complex enters cells and localises to the mitochondria, demonstrating cell permeability. Further, an appreciable yield of singlet oxygen generation $\left(\Phi_{\Delta}=0.45\right.$, direct method, by ${ }^{1} \mathrm{O}_{2}$ NIR emission in air equilibrated acetonitrile) suggests a possible future use in photodynamic therapy. However, the complex has relatively high dark toxicity $\left(\mathrm{LD}_{50}=4.46 \mu \mathrm{M}\right)$, which will likely hinder its clinical application. Despite this toxicity, the broad emission spectrum of the complex and high emission yield observed suggest a possible future use of this class of compound in emission bioimaging. The presence of two heavy atoms also increases the scattering of electrons, supporting potential future applications as a dual fluorescence and electron microscopy probe.

Received 10th January 2018

Accepted 1st March 2018

DOI: $10.1039 / \mathrm{c} 8 \mathrm{ra00265g}$

rsc.li/rsc-advances
In the field of transition metal complexes for use in bioimaging, ruthenium, rhenium and platinum complexes dominated the early literature. However, iridium complexes with high emission quantum yields and localisation to a wide variety of sub-cellular organelles have seen a surge in popularity over the last decade. ${ }^{6-11}$ In PDT, ruthenium complexes have dominated the field of transition metal photosensitizers ${ }^{12-16}$ with one $\mathrm{Ru}(\mathrm{II})$ complex having entered clinical trials in Canada. ${ }^{17,18} \mathrm{In}$ comparison, iridium complexes in PDT are yet to be fully explored. Importantly a few iridium complexes have been recently shown to have photo-toxicities at low light doses under both one-19-25 and two-photon excitation, ${ }^{26-30}$ suggesting that Ir(III) containing complexes hold future potential for PDT.

Previously we reported several families of highly luminescent transition metal (TM) complexes linked by cyclometallating ditopic ligands. ${ }^{31-34}$ In comparison with their monometallic analogues, these polynuclear complexes show red-shifted absorption and luminescence properties that may minimise the background auto-fluorescence in imaging of biological objects. In addition, the appreciable molar extinction coefficient of the low-energy absorption band and high quantum yields make them good imaging agents. The red-shift of the absorption band is also advantageous for PDT because it allows for excitation by wavelengths of light with greater tissue depth penetration. The highest quantum yields we previously observed with any of the complexes (up to $100 \%$ ) were for the di-

$\dagger$ Electronic supplementary information (ESI) available. See DOI $10.1039 / \mathrm{c} 8 \mathrm{ra00265g}$

\$ These authors contributed equally. 

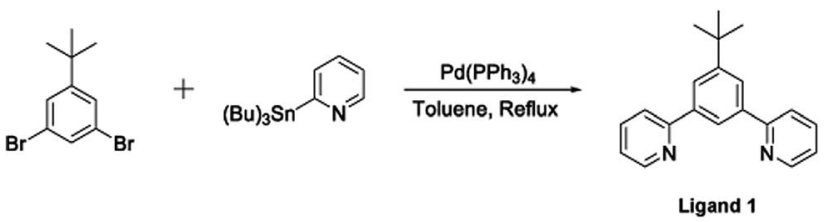

Fig. 1 Synthesis of the terdentate proligand (Ligand 1) via a Stille cross-coupling reaction.

iridium(III) complexes formed by ditopic bis- $\mathrm{N}^{\wedge} \mathrm{C}$ ligands in conjunction with symmetrically-substituted terminal $\mathrm{N}^{\wedge} \mathrm{C}^{\wedge} \mathrm{N}$ ligands. ${ }^{35}$ These complexes were also the easiest to synthesise because the iridium centres are achiral and the formation of diastereomers is not possible; the strong trans influence of the metallated rings of both the $\mathrm{N}^{\wedge} \mathrm{C}^{\wedge} \mathrm{N}$ and bis- $\mathrm{N}^{\wedge} \mathrm{C}$ ligands directs the relative positions of these ligands around the iridium centres so that only one product is formed. ${ }^{35}$ The presence of two closely positioned heavy atoms might also increase the scattering of electrons suggesting the use of di-iridium complexes as contrast reagents and thus combined with the high quantum yields as dual-modality agents. However, all the complexes prepared so far were designed for applications in organic light emitting diodes and none are soluble in water.
Here, motivated by the advantages offered by bimetallic Ir(III) complexes, we sought to adapt the complexes by incorporating pyridazine as a bridging heterocycle. The close proximity of Ir atoms causes the $\mathrm{Cl}$ atom to act as a bridging ligand. Five chelate rings form as a result, providing the driving force for the reaction and leading to a rigid architecture. Another consequence of the bridging $\mathrm{Cl}$ atom is that the complex becomes ionic, which somewhat improves solubility in water. Once synthesised, we characterised the complex and examined its ability to enter cells, its sub-cellular localisation and its cellular toxicity. In addition, it's use as a contrasting reagent in transmission electron microscopy (TEM) was assessed.

\section{Results and discussion}

\subsection{Synthesis}

The terdentate proligand, 2-[3-tert-butyl-5-(pyridin-2-yl)phenyl] pyridine (Ligand 1), was prepared using Stille cross-coupling methodology (Fig. 1) and was isolated in good yield. Chou et al. previously reported the synthesis of this terdentate ligand via an alternative Suzuki-Miyaura cross-coupling route. The inclusion of a tert-butyl substituent at the 5-position of the

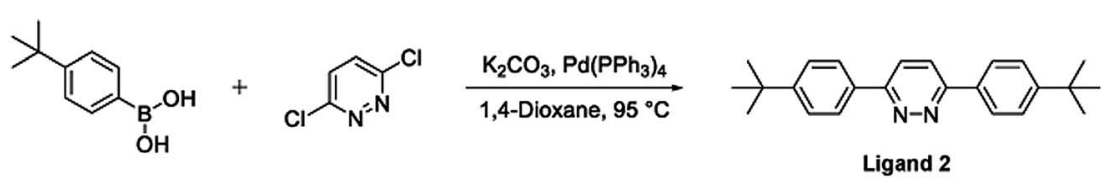

Fig. 2 Synthesis of the bis $-\mathrm{N}^{\wedge} \mathrm{C}$ coordinating bridging ligand (Ligand 2) via a Suzuki-Miyaura cross-coupling reaction.

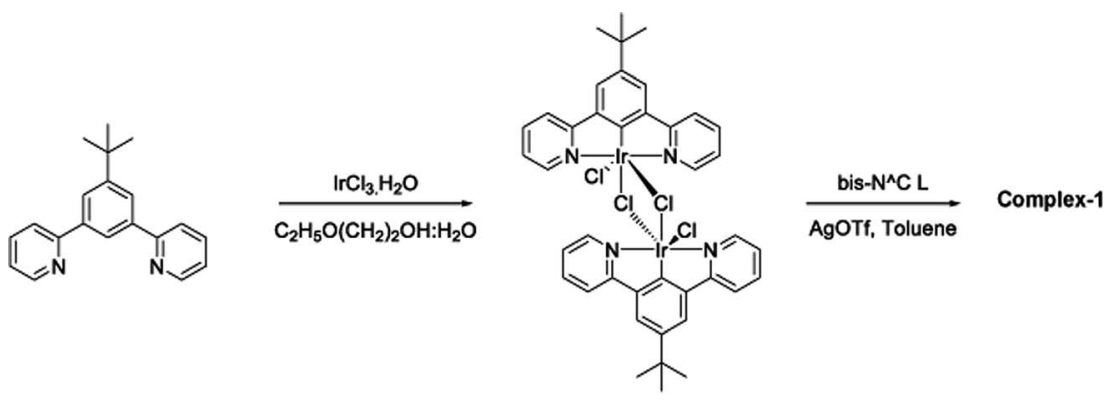

Fig. 3 Synthesis of $\left[\left(N^{\wedge} C^{\wedge} N\right){ }_{2} \mid r\left(\right.\right.$ bis- $\left.\left.-N^{\wedge} C\right) \operatorname{Ir}\left(N^{\wedge} C^{\wedge} N\right)_{2} C l\right] P F_{6}\left(N^{\wedge} C^{\wedge} N=2-\left[3\right.\right.$-tert-butyl-5-(pyridin-2-yl)phenyl]pyridine; bis- $N^{\wedge} C=3,6$-bis $(4-$ tert-butylphenyl)pyridazine) (complex-1) by reaction of dichloro-bridged iridium(III) dimer with the bis-bidentate proligand in toluene, using silver triflate as a chloride scavenger.
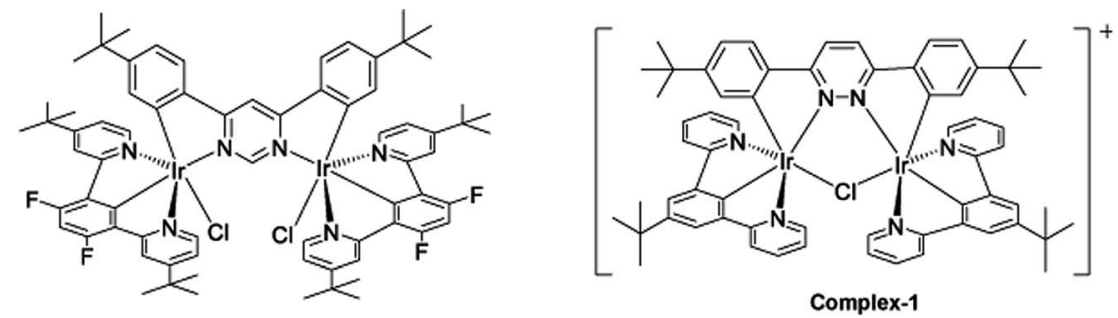

Fig. 4 Changing bridging heterocycle from pyrimidine to pyridazine leads to cationic di-Ir complex (complex-1). 
Table 1 Summary of the photophysical data for 1

\begin{tabular}{|c|c|c|c|c|c|}
\hline Compound & $\lambda_{\max }{ }^{a}[\mathrm{~nm}]\left(\varepsilon\left[\times \mathrm{dm}^{3} \mathrm{~mol}^{-1} \mathrm{~cm}^{-1}\right]\right)$ & $\lambda_{\mathrm{em}}^{a, b}(\max )$ & $\tau_{0}, \tau_{1}, \tau_{2}^{a, c}[\mathrm{~ns}]$ & $\Phi_{0}, \Phi_{1}^{a, b, d}[\%]$ & $\Phi_{\Delta}^{a, e}[\%]$ \\
\hline 1 & 235 (79 900), 284 (54 700), 397 (24 200) & 576 & $1890,226,561 / 103$ & 62,5 & 45 \\
\hline
\end{tabular}

central phenyl ring ensures terdentate coordination to an iridium(III) metal centre. ${ }^{36}$

The synthesis of the bis- $\mathrm{N}^{\wedge} \mathrm{C}$ coordinating proligand, 3,6bis(4-tert-butylphenyl)pyridazine (Ligand 2), was achieved through a Suzuki-Miyaura cross-coupling reaction between 3,6dichloropyridazine and 4-(tert-butyl)phenylboronic acid (Fig. 2). The desired product was isolated in good yield. A similar synthetic route for the preparation of 3,6-bis(4-tert-butylphenyl) pyridazine was previously published by Wang and co-workers. ${ }^{37}$

The target dinuclear complex was prepared using a similar synthetic method to that developed by Williams. ${ }^{35}$ Firstly, the

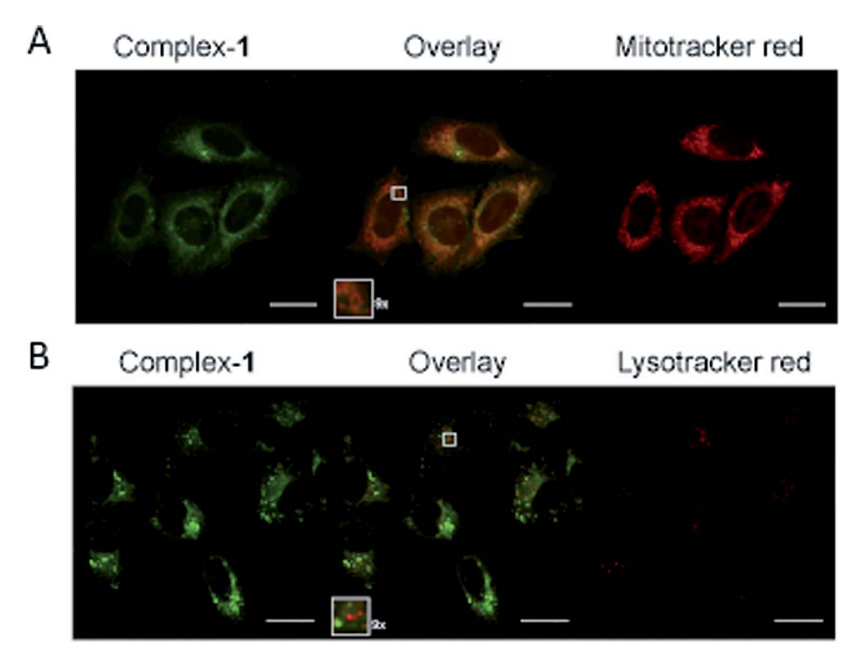

Fig. 5 Sub-cellular localisation of complex-1. HeLa cells following 5 hour incubation with $10 \mu \mathrm{M}$ complex-1 (green), colocalised with (A) Mitotracker orange (red) or (B) Lysotracker (red). Zoomed sections $(\times 9)$ are shown as insets. Scale bars $=20 \mu \mathrm{m}$. terdentate Ligand 1 was reacted with $\operatorname{IrCl}_{3} \cdot \mathrm{H}_{2} \mathrm{O}$ at reflux in a mixture of 2-ethoxyethanol and water to give the dichlorobridged iridium dimer, $\left[\operatorname{Ir}\left(\mathrm{N}^{\wedge} \mathrm{C}^{\wedge} \mathrm{N}\right) \mathrm{Cl}(\mu-\mathrm{Cl})\right]_{2}$. in $85 \%$ yield. The dimer was then reacted with the bis-bidentate proligand in toluene, using silver triflate as a chloride scavenger (Fig. 3). Upon completion of the reaction, the mixture was treated with excess $\mathrm{HCl}(3 \mathrm{M}$, aq.) in order to ensure that the only monodentate ligand present on an iridium centre is chloride. Following this, a $\mathrm{Cl} / \mathrm{PF}_{6}$ anion exchange was carried out using a saturated solution of $\mathrm{KPF}_{6}(\mathrm{aq})$. Purification was carried out using column chromatography to give the target complex 1 (Fig. 4), in 38\% yield. ${ }^{35}$ The complex was characterised by ${ }^{1} \mathrm{H}$ and spectroscopy and high resolution mass spectrometry (ESI S3†).

\subsection{Photophysical studies}

In acetonitrile solution, $\mathbf{1}$ shows broad absorbtion in the UV/vis region with appreciable absorption up to $\sim 500 \mathrm{~nm}$. Upon excitation $\left(\lambda_{\mathrm{exc}}=400 \mathrm{~nm}\right) 1$ shows broad emission $\left(\lambda_{\mathrm{em}}=\sim 520-\right.$ $720 \mathrm{~nm})$. An emission lifetime of $1.9 \mu$ s and a quantum yield of $62 \%( \pm 11 \%)$ was measured in deaerated (by bubbling $\mathrm{N}_{2}$ ) acetonitrile solution. Emission q.y. decreased $\sim 10$-fold, to 5\%, in aerated solution indicating significant quenching of the emissive state by oxygen. The singlet oxygen yield, $\Phi_{\Delta}=0.45$ was measured by direct detection of the ${ }^{1} \mathrm{O}_{2}$ emission $(1270 \mathrm{~nm})$ under UV excitation $\left(\lambda_{\text {exc }}=355 \mathrm{~nm}\right)$. The appreciable singlet oxygen yield showed the potential for this class of compounds as therapeutic agents (Table 1 and ESI S1†).

\subsection{Luminescent imaging and sub-cellular localisation}

The complex is moderately soluble in water, DMSO was used to assist solubilisation with the final concentration of DMSO always $\leq 2 \%$.
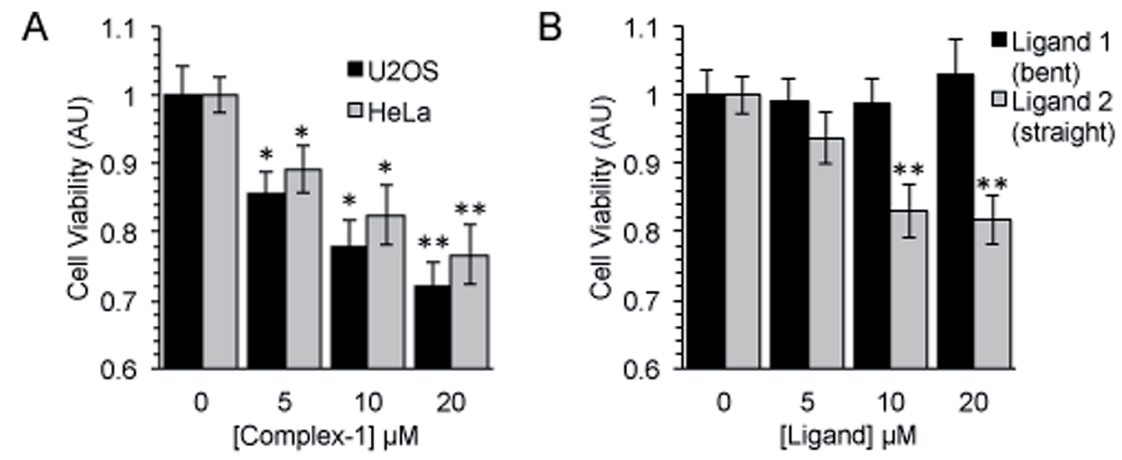

Fig. 6 Complex-1 and Ligand 2 induce a significant reduction in cell viability. Cell viability as measured by MTT assay after a 5 hour incubation with (A). Complex-1 in HeLa and U2OS cells and (B). Ligands as indicated in HeLa cells. Mean and SEM of 4 independent repeats is shown. Significance calculated by Student's $T$-test compared to respective untreated control is indicated, where $*=p<0.05$ and $* *=p<0.01$. 
Emission microscopy of live cells incubated with $10 \mu \mathrm{M} \mathrm{1}$, performed under multiphoton excitation $\left(\lambda_{\text {exc }}=800 \mathrm{~nm}\right)$, showed that 1 enters cells and localises in the cytoplasm with distinct punctate staining (ESI S2 $\dagger$ ). These results are consistent with those reported previously for cationic metal complexes, which are known to locate in mitochondrial and lysosomal structures. $^{38}$ Co-localisation of $\mathbf{1}$ with mitochondria was confirmed using organelle specific stains and confocal microscopy $\left(\lambda_{\text {exc }}=405 \mathrm{~nm}\right.$ ) (Fig. 5A), giving a Pearson's correlation coefficient of $R=0.76$ (averaged over 15 cells) for mitotracker

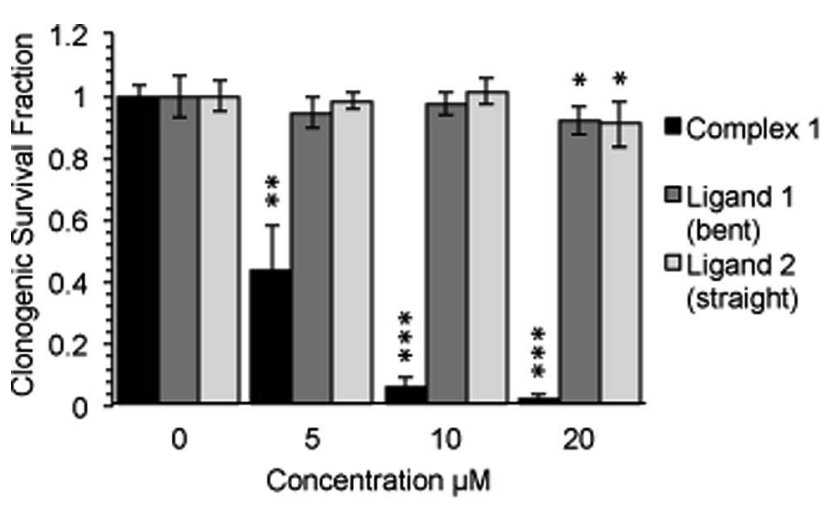

Fig. 7 Complex-1 reduces cell survival to a significantly greater degree than each ligand alone. Long term survival (10 days) as measured by clonogenic survival assay after a 5 hour incubation with complex-1/Ligands as indicated in HeLa cells. Mean and SD of 2 independent repeats (each conducted in duplicate is shown). Significance calculated by Student's $T$-test compared to respective untreated control is indicated, where $*=p<0.05, * *=p<0.01$ and $* * *=p<0.001$. red. Co-localisation of $\mathbf{1}$ with lysotracker red was not observed (Fig. 5B) indicating that the punctate staining may result from other endosomal structures (Pearson's correlation coefficient of $R=0.53$ with lysotracker red (averaged over 15 cells)).

\subsection{Cellular toxicity}

Following an incubation time of 5 hours to mimic imaging conditions, 1 induced a significant dose dependent reduction in metabolic activity/cell viability in both U2OS and HeLa cancer cell lines as indicated by MTT assay (Fig. 6A). The effect of the associated ligands was also measured. Ligand 1, did not reduce cell viability whilst Ligand 2 , induced a similar reduction in metabolic activity as 1 (Fig. 6B). The MTT assay measures the metabolic activity of a cell, and thus is considered a read out of cell viability, however it is not a measure of long-term cell survival. A clonogenic survival assay was used in order to obtain an assessment of the cellular toxicity. In these assays, cells were plated at low density prior to a 5 hour incubation with 1 or its associated ligands, subsequently cells were left to recover and form colonies for 10 days. In this more reliable assay of cell toxicity 1 showed significant toxicity $\left(\mathrm{LD}_{50}=4.46 \mu \mathrm{M}\right)$ while the associated ligands induced only slight toxicity at the highest doses tested $\left(\mathrm{LD}_{50} \geq 20 \mu \mathrm{M}\right)$ (Fig. 7). Taken together the MTT and clonogenic survival data reveal that while Ligand 2 transiently effects the metabolic activity of cells, over the short term 1 is significantly more cytotoxic to cells than either of the ligands.

\subsection{Transmission electron microscopy (TEM)}

Dual-modality imaging agents have district advantages over agents used in a single method, combining strengths of
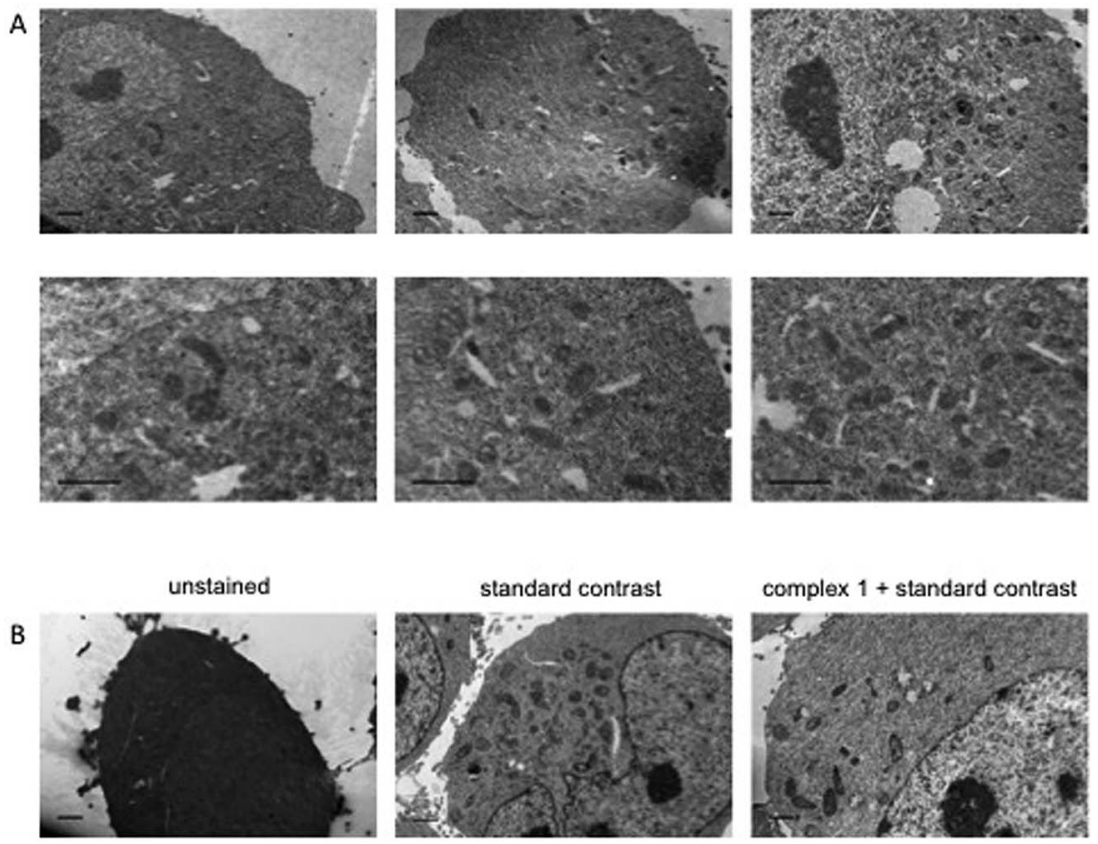

Fig. 8 Transmission Electron Microscopy images of HeLa cells using complex-1 as contrast agent. Cells incubated with or without $20 \mu \mathrm{M}$ complex-1 for $4 \mathrm{~h}$, example images with and without standard contrast ("double contrasting", with uranyl acetate and lead citrate). (A) Example images of staining with complex-1 alone. (B) Example images of cells unstained, stained using standard double contrast agents and stained with complex-1 plus standard agents. Scale bars $=1 \mu \mathrm{m}$. 
individual imaging techniques. The potential of $\mathbf{1}$ as a staining agent in transmission electron microscopy (TEM) was evaluated as follows. Live U2OS cells were incubated with $1(20 \mu \mathrm{M}, 4$ hours), fixed, processed for TEM in the presence or absence of standard contrasting agents, and imaged (Fig. 8). Contrast in the cells stained with 1 was enhanced compared to unstained cells. Interestingly 1 also increased contrast in organelles other than mitochondria, this raises the possibility that the microenvironment in live cells means that luminescence is greater in the mitochondria, alternatively the complex might leak and diffuse around the cell while being prepped for TEM as we didn't use any $\mathrm{OsO}_{4}$ which acts as a secondary fixative. Importantly, 1 did not interfere with standard contrast enhancing reagents (uranyl acetate and lead citrate).

\section{Conclusion}

We have demonstrated that a novel pyridazine-bridged cationic di-iridium complex can enter live cells, has photo-physical properties favourable for imaging applications, and generates singlet oxygen in considerable yield. However, due to high dark cytotoxicity, this complex is unlikely to be suitable for PDT applications. Instead, the toxicity of the complex could be exploited in other applications where its intrinsic toxicity could be beneficial, such as development of new anticancer agents. The photophysical properties of the complexes are of interest for luminescent bioimaging and the presence of two heavy atoms allows its use as a contrast agent in TEM. Potentially, the structure of the complex can be varied trough modification of both bridging and auxiliary ligands as well as by employing different metals to fine-tune the properties and reduce toxicity.

\section{Materials and methods/ experimental section}

\subsection{Synthesis and characterisation}

4.1.1. Ligand $1 .^{36}$ A mixture of 1,3-dibromo-5-(tert-butyl) benzene (3.01 g, $10.3 \mathrm{mmol}$ ), 2-(tributylstannyl)pyridine (9.54 g, $25.7 \mathrm{mmol}$ ) and tetrakis(triphenylphosphine)palladium (0.358 g, $0.309 \mathrm{mmol}$ ) were added to toluene $(100 \mathrm{~mL})$ and the reaction mixture degassed for $15 \mathrm{~min}$ under argon. The reaction mixture was heated to reflux $\left(140^{\circ} \mathrm{C}\right)$ for $20 \mathrm{~h}$. The reaction mixture was purified by column chromatography (silica gel, petroleum ether : ethyl acetate $100: 0$ to $4: 1$ to $6: 1$ to $3: 1$ ) and a white solid was obtained $(2.11 \mathrm{~g}, 7.31 \mathrm{mmol}, 71 \%) .{ }^{1} \mathrm{H}$ NMR $(400 \mathrm{MHz}$, $\left.\mathrm{CDCl}_{3}\right): \delta 8.72(\mathrm{~d}, 2 \mathrm{H}, J=1.6), 8.34(\mathrm{~d}, 1 \mathrm{H}, J=1.4), 8.12(\mathrm{~d}, 2 \mathrm{H}, J$ $=1.4), 7.82(\mathrm{~d}, 2 \mathrm{H}, J=7.8), 7.76(\mathrm{t}, 2 \mathrm{H}, J=7.8), 7.26-7.23(\mathrm{~m}$, 2H), $1.45(\mathrm{~s}, 9 \mathrm{H}) ;{ }^{13} \mathrm{C} \mathrm{NMR}\left(\mathrm{CDCl}_{3}, 100 \mathrm{MHz}\right): \delta 157.83(\mathrm{C}), 152.23$ (C), $149.66(\mathrm{CH}), 139.71(\mathrm{C}), 136.67(\mathrm{CH}), 124.75(\mathrm{CH}), 123.02$ $(\mathrm{CH}), 122.08(\mathrm{CH}), 120.93(\mathrm{CH}), 35.12(\mathrm{C}), 31.48\left(\mathrm{C}-\left(\mathrm{CH}_{3}\right)_{3}\right)$.

4.1.2. Ligand $2 .{ }^{37}$ 3,6-Dichloropyridazine (0.497 g, 3.33 $\mathrm{mmol})$, (4-tert-butylphenyl)boronic acid ( $1.54 \mathrm{~g}, 8.67 \mathrm{mmol})$ and a $2 \mathrm{M}$ aqueous potassium carbonate solution $(2.76 \mathrm{~g}$, $20.0 \mathrm{mmol}, 10.0 \mathrm{~mL}$ ) were added to a round-bottomed flask. 1,4Dioxane $(25 \mathrm{~mL})$ was added. The mixture was degassed under argon for $20 \mathrm{~min}$. Tetrakis(triphenylphosphine)palladium
$(0.231 \mathrm{~g}, 0.200 \mathrm{mmol})$ was added and the reaction mixture degassed for a further 10 minutes. The reaction was heated to $95{ }^{\circ} \mathrm{C}$ for $42 \mathrm{~h}$. The reaction was cooled to room temperature. A precipitate formed and this precipitate was filtered in vacuo. The solid was then recrystallised from dimethylformamide to give the product as a silver solid $(0.659 \mathrm{~g}, 1.91 \mathrm{mmol}, 57 \%) .{ }^{1} \mathrm{H} \mathrm{NMR}$ $\left(\mathrm{CDCl}_{3}, 400 \mathrm{MHz}\right): \delta 8.11$ (d, $\left.4 \mathrm{H}, J=8.2\right), 7.90$ (s, 2H), 7.57 (d, $4 \mathrm{H}, J=8.2), 1.39(\mathrm{~s}, 18 \mathrm{H}) ;{ }^{13} \mathrm{C}$ DEPT135 NMR $\left(\mathrm{CDCl}_{3}, 400 \mathrm{MHz}\right)$ : $\delta 157.24(\mathrm{C}), 153.28(\mathrm{C}), 133.33(\mathrm{C}), 126.58(\mathrm{C}-\mathrm{H}), 126.02(\mathrm{CH})$, $123.86(\mathrm{CH}), 34.83(\mathrm{C}), 31.26\left(\mathrm{C}-\left(\mathrm{CH}_{3}\right)_{3}\right)$.

\subsubsection{1}

Step 1. A mixture of 1,3-di(2-pyridyl)-5-(tert-butyl)benzene Ligand $1(0.609 \mathrm{~g}, 2.08 \mathrm{mmol})$ and iridium chloride hydrate $(0.768 \mathrm{~g}, 2.08 \mathrm{mmol})$ were added to a $3: 1$ mixture of 2-ethoxyethanol and water $(100 \mathrm{~mL})$. The reaction mixture was heated to reflux (bath temperature $130{ }^{\circ} \mathrm{C}$ ) for $24 \mathrm{~h}$ under argon and then allowed to cool to room temperature. The resulting orange solid was filtered off, washed with ethanol and water to give intermediate dichlorobridged iridium complex $(0.972 \mathrm{~g}$, $1.77 \mathrm{mmol}$, 85\%) which was used in the following step without further purification.

Step 2. The dichlorobridged iridium complex from step 1 $(0.170 \mathrm{~g}, 0.308 \mathrm{mmol})$ was added to a round-bottomed flask. Toluene $(30 \mathrm{~mL})$ was added and the mixture stirred. Silver triflate $(0.122 \mathrm{~g}, 0.463 \mathrm{mmol})$ was added. 3,6-Bis(4-tert-butylphenyl)pyridazine Ligand 2 (0.0531 g, $0.154 \mathrm{mmol}$ ) was added and the reaction mixture was heated to reflux for $15 \mathrm{~h}$. The reaction mixture was removed from the heat and $3 \mathrm{M}$ hydrochloric acid solution (7 mL) was added. The mixture was stirred for $5 \mathrm{~min}$. The solvent was evaporated to dryness. A mixture of $1: 1$ acetonitrile : water $(4 \mathrm{~mL})$ was added to the residue. To the solution formed, excess saturated aqueous ammonium hexafluorophosphate solution was added. An orange solid precipitated and was filtered in vacuo to give the crude product $(0.233 \mathrm{~g}$, $0.174 \mathrm{mmol}$ ). The product was then purified by column chromatography (silica gel, DCM : EtOAc 10:1). Yellow solid (0.0781 g, $0.0584 \mathrm{mmol}, 38 \%) .{ }^{1} \mathrm{H} \mathrm{NMR}\left(\mathrm{CDCl}_{3}, 400 \mathrm{MHz}\right): \delta 8.72$ (s, 2H), 8.00 (d, $4 \mathrm{H}, J=5.0), 7.71(\mathrm{dd}, 6 \mathrm{H}, J=8.2,3.2), 7.689$ (s, $4 \mathrm{H}), 7.50(\mathrm{td}, 4 \mathrm{H}, J=7.3,1.8), 6.94-6.92(\mathrm{~m}, 6 \mathrm{H}), 6.00(\mathrm{~d}, 2 \mathrm{H}, J=$ 1.8), 1.37 (s, 18H), 0.87 (s, 18H). HRMS $\left(\mathrm{FTMS}^{+}\right)$for $[\mathrm{M}]^{+}$calcd. 1337.4129 , found 1337.4144 ; for $[\mathrm{M}-(\mathrm{Ir}(\mathrm{NCN}))-\mathrm{Cl}]^{+}$calcd. 823.0780, found 823.3359.

\subsection{Photophysical studies}

The UV/vis spectra were recorded on Varian Cary 5000 UV-visNIR spectrophotometer in $1 \mathrm{~cm}$ quartz cuvettes. The luminescence spectra were recorded on Fluoromax 4 spectrofluorimeter (HORIBA Jobin Yvon). Emission lifetime measurements were performed on the mini- $\tau$ spectrofluorometer (Edinburgh Instruments), with $405 \mathrm{~nm}$ pulsed diode laser as an excitation source. The emission decays were detected in the spectral range 475-525 $\mathrm{nm}$ selected by a bandpass filter.

\subsection{Singlet oxygen yield}

The singlet oxygen yield of the compound was measured by direct detection of the singlet oxygen emissiton $\left(\lambda_{\mathrm{em}}=1270 \mathrm{~nm}\right.$, 
detected with a cut-off $>1100 \mathrm{~nm}$ filter) in aerated acetonitrile against the standard perinapthenone with UV excitation $\left(\lambda_{\mathrm{ex}}=\right.$ $355 \mathrm{~nm}$ ), according to the method previously described. ${ }^{26}$

\subsection{Cell culture}

Both cell lines HeLa (human cervical cancer) and U2OS (bone osteosarcoma) were purchased from American Type Culture Collection - LGC partnership (Teddington, UK). The cells were cultured in Dulbecco's modified Eagles Medium (DMEM) (Lonza, Cambridge UK) with 10\% fetal calf serum (FCS) (Lonza, Cambridge UK) and incubated at $37{ }^{\circ} \mathrm{C}\left(5 \% \mathrm{CO}_{2}\right)$. Cells were routinely checked for mycoplasma contamination.

\subsection{Cell imaging}

Cells were plated at 150000 cells per well onto sterile coverslips $(22 \times 22 \mathrm{~mm})$. Following over night incubation, 10 or $20 \mu \mathrm{M}$ final concentration of $\mathbf{1}$ (diluted from $1 \mathrm{mM}$ stock solution in DMSO) was added to cells, control wells were incubated with equivalent DMSO concentration and plates were incubated for 5 hours. Following incubation, the cells were washed (3 X PBS) and fixed (4\% paraformaldehyde in PBS, $20 \mathrm{~min}$ ) before being washed ( 3 X PBS) and mounted to microscope slides (immumount, $20 \mathrm{~min}$ ). For mitotracker red staining (MitoTracker ${ }^{\mathrm{TM}}$ Red CMXRos, Molecular Probes ${ }^{\circledR}$ by Life Technologies Ltd, Paisley, UK) a final staining concentration of $100 \mathrm{nM}$ was added to the cells in $30 \mathrm{~min}$ before washing, fixing and mounting. For lysotracker red staining (LysoTracker ${ }^{\mathrm{TM}}$ Red DND-99, Molecular Probes ${ }^{\circledR}$ by Life Technologies Ltd, Paisley, UK) a final staining concentration of $75 \mathrm{nM}$ was added for 1 hour before washing, fixing and mounting.

For the multiphoton imaging (Coherent Chameleon femtosecond pulsed laser, Inverted Zeiss LSM 510 NLO microscope) $800 \mathrm{~nm}$ was used to excite 1; emission was registered in the region 565-615 nm For the co-localisation imaging a confocal microscope was used (Nikon A1) with a $60 \times$ lens (CFI Plan Apochromat VC $60 \times$ oil, NA 1.4). A diode laser (405 nm) was used to excite 1 and a sapphire laser $(561 \mathrm{~nm})$ was used to excite the co-stains. Pearson's correlation coefficients were calculated using the open source imaging software Fiji (based on ImageJ) and the coloc 2 colocalisation tool. The threshold regression chosen was Bisection.

\subsection{Proliferation assay - MTT}

96-well plates were seeded with cells (HeLa or U2OS at 8000/ well) in culture media (DMEM with 10\% FCS) and incubated $\left(37^{\circ} \mathrm{C}, 5 \% \mathrm{CO}_{2}\right.$, overnight). Treatment solutions were made up in media (DMEM with $10 \%$ FCS) with the compound diluted from a DMSO stock $(1 \mathrm{mM})$ to the desired staining concentrations $(0,5,10$ and $20 \mu \mathrm{M})$ with the final concentration of DMSO equal in all samples $(2 \%)$

\subsection{Toxicity assay - clonogenic survival}

6-well plates were seeded at low density (HeLa, 200 and 400 cells per well) in culture medium (DMEM with $10 \%$ FCS) and incubated $\left(37{ }^{\circ} \mathrm{C}, 5 \% \mathrm{CO}_{2}\right.$, overnight). Treatment solutions were prepared as above and added ( $1 \mathrm{~mL}$ per well, 5 hours). Following incubation the treatment solution was removed and cells washed (1 X PBS) and fresh media was added ( $2 \mathrm{~mL}$ per well). The plates were left until visible cell colonies had formed. Media was replaced with staining solution ( $4 \%$ methylene blue, $70 \%$ methanol, minimum $30 \mathrm{~min}$ ). The staining solution was washed off and colonies counted with each colony representing a surviving cell.

\subsection{Transmission electron microscopy}

HeLa cells were cultured in T-25 flasks as above until $\sim 90 \%$ confluency is achieved. Media was then removed and the cells washed with sterile PBS $(5 \mathrm{~mL})$ before incubation with $20 \mu \mathrm{M} 1$ for $4 \mathrm{~h} .1$ was the removed and the cells washed with sterile PBS $(2 \times 5 \mathrm{~mL})$. Cells were detached using Trypsin EDTA, washed in media and glutaraldehyde $(2.5 \%$ in cacodylate buffer $)$ was added to fix the cells overnight at $\sim 4{ }^{\circ} \mathrm{C}$. Cells were then dehydrated, embedded in Araldite and sectioned in to $85 \mathrm{~nm}$ sections and mounted on copper grids before imaging under TEM having either been unstained or stained with standard contrast agent $\left(\mathrm{OsO}_{4} 2 \%, 1 \mathrm{~h}, \mathrm{UAc}_{2} 3 \%, 25 \mathrm{~min}\right.$, Reynold's Lead Citrate, $5 \mathrm{~min}$ ). All TEM imaging was carried out using a FEI tecnai $120 \mathrm{Kv}$ G2 Biotwin TEM with an Orius SC100 bottom mounted camera using Gatan Digital Micrograph software. Image analysis was performed using image J.

\section{Author contributions}

VK, JW and HB conceived and designed the study, RD synthesised and characterised all compounds, LM performed the photo-physical analysis and toxicity assays, LM and JS performed the imaging, RD, LM, JW, JS, VK and HB wrote the manuscript.

\section{Competing financial interests}

The authors declare no competing financial interests.

\section{Acknowledgements}

This work was funded jointly by University of Sheffield, Northumbria University, Yorkshire Cancer Research, Cancer Research UK, BBSRC, EPSRC KTA, MRC POC funds, Welcome Trust grant WT093134AIA and MRC SHIMA award MR/K015753/1. The authors would like to thank Dr D. Robinson for help in capturing images.

\section{References}

1 E. Baggaley, S. W. Botchway, J. W. Haycock, H. Morris, I. V. Sazanovich, J. A. G. Williams and J. A. Weinstein, Chem. Sci., 2014, 5, 879-886.

2 A. Martin, A. Byrne, C. S. Burke, R. J. Forster and T. E. Keyes, J. Am. Chem. Soc., 2014, 136, 15300-15309.

3 A. Parapaleix, Y. G. Houssen and S. Charpak, Nat. Med., 2013, 19, 241-246. 
4 Y. Chen, L. Qiao, L. Ji and H. Chao, Biomaterials, 2014, 35, 213.

5 K. Qui, H. Huang, B. Liu, Y. Liu, Z. Huang, Y. Chen, L. Ji and H. Chao, ACS Appl. Mater. Interfaces, 2016, 8, 12702-12710.

6 E. Baggaley, J. A. Weinstein and J. A. G. Williams, Coord. Chem. Rev., 2012, 256, 1762-1785.

7 Y. You, Curr. Opin. Chem. Biol., 2013, 17, 699-707.

8 K. YináZhang, Chem. Comm., 2015, 51, 7943-7946.

9 K. Y. Zhang, S. P.-Y. Li, N. Zhu, I. W.-S. Or, M. S. H. Cheung, Y.-W. Lam and K. K.-W. Lo, Inorg. Chem., 2010, 49, 25302540.

10 T. F. Anjong, G. Kim, H. Y. Jang, J. Yoon and J. Kim, New J. Chem., 2016, 41, 377-386.

11 C. Ho, K.-L. Wong, H.-K. Kong, Y.-M. Ho, C.-L. Chan, W.-M. Kwok, K.-Y. Leung, H.-L. Tam, M.-W. Lam and X.-F. Ren, Chem. Commun., 2012, 48, 2525-2527.

12 A. Frei, R. Rubbiani, S. Tubafard, O. Blacque, P. Anstaett, A. Felgenträger, T. Maisch, L. Spiccia and G. Gasser, J. Med. Chem., 2014, 57, 7280-7292.

13 H. Huang, B. Yu, P. Zhang, J. Huang, Y. Chen, G. Gasser, L. Ji and H. Chao, Angew. Chem., Int. Ed., 2015, 127, 14255-14258.

14 J. Hess, H. Huang, A. Kaiser, V. Pierroz, O. Blacque, H. Chao and G. Gasser, Chem.-Eur. J., 2017, 23, 9888-9896.

15 C. Mari and G. Gasser, Chimia, 2015, 69, 176-181.

16 M. G. Walker, P. J. Jarman, M. R. Gill, X. Tian, H. Ahmad, P. A. Reddy, L. McKenzie, J. A. Weinstein, A. Meijer and G. Battaglia, Chem.-Eur. J., 2016, 22, 5996-6000.

17 J. Fong, K. Kasimova, Y. Arenas, P. Kaspler, S. Lazic, A. Mandel and L. Lilge, Photochem. Photobiol. Sci., 2015, 14, 2014-2023.

18 S. Lazic, P. Kaspler, G. Shi, S. Monro, T. Sainuddin, S. Forward, K. Kasimova, R. Hennigar, A. Mandel and S. McFarland, Photochem. Photobiol., 2017, 93, 1248-1258.

19 Y. Li, C.-P. Tan, W. Zhang, L. He, L.-N. Ji and Z.-W. Mao, Biomaterials, 2015, 39, 95-104.

20 C. Mari, H. Huang, R. Rubbiani, M. Schulze, F. Würthner, H. Chao and G. Gasser, Eur. J. Inorg. Chem., 2016, 2017, 1745-1752.

21 S. P.-Y. Li, C. T.-S. Lau, M.-W. Louie, Y.-W. Lam, S. H. Cheng and K. K.-W. Lo, Biomaterials, 2013, 34, 7519-7532.

22 L. He, Y. Li, C.-P. Tan, R.-R. Ye, M.-H. Chen, L.-N. Ji and Z.-W. Mao, Chem. Sci., 2015, 6, 5409-5418.
23 R.-R. Ye, C.-P. Tan, L. He, M.-H. Chen, L.-N. Ji and Z.-W. Mao, Chem. Commun., 2014, 50, 10945-10948.

24 F. Xue, Y. Lu, Z. Zhou, M. Shi, Y. Yan, H. Yang and S. Yang, Organometallics, 2014, 34, 73-77.

25 D. Maggioni, M. Galli, L. D'Alfonso, D. Inverso, M. V. Dozzi, L. Sironi, M. Lannacone, M. Collini, P. Ferruti and E. Ranucci, Inorg. Chem., 2015, 54, 544-553.

26 L. K. McKenzie, I. V. Sazanovich, E. Baggaley, M. Bonneau, V. Guerchais, J. A. G. Williams, J. A. Weinstein and H. E. Bryant, Chem.-Eur. J., 2017, 23, 234-238.

27 X. Tian, Y. Zhu, M. Zhang, L. Luo, J. Wu, H. Zhou, L. Guan, G. Battaglia and Y. Tian, Chem. Commun., 2017, 53, 33033306.

28 J. Liu, C. Jin, B. Yuan, X. Liu, Y. Chen, L. Ji and H. Chao, Chem. Commun., 2017, 53, 2052-2055.

29 J. S. Nam, M.-G. Kang, J. Kang, S.-Y. Park, S. J. C. Lee, H.-T. Kim, J. K. Seo, O.-H. Kwon, M. H. Lim and H.-W. Rhee, J. Am. Chem. Soc., 2016, 138, 10968-10977.

30 E. M. Boreham, L. Jones, A. N. Swinburne, M. BlanchardDesce, V. Hugues, C. Terryn, F. Miomandre, G. Lemercier and L. S. Natrajan, Dalton Trans., 2015, 44, 16127-16135.

31 V. N. Kozhevnikov, M. C. Durrant and J. A. G. Williams, Inorg. Chem., 2011, 50, 6304-6313.

32 S. Culham, P.-H. Lanoë, V. L. Whittle, M. C. Durrant, J. A. G. Williams and V. N. Kozhevnikov, Inorg. Chem., 2013, 52, 10992-11003.

33 P.-H. Lanoë, C. M. Tong, R. W. Harrington, M. R. Probert, W. Clegg, J. A. G. Williams and V. N. Kozhevnikov, Chem. Commun., 2014, 50, 6831-6834.

34 G. Turnbull, J. A. G. Williams and V. N. Kozhevnikov, Chem. Commun., 2017, 53, 2729-2732.

35 R. E. Daniels, S. Culham, M. Hunter, M. C. Durrant, M. R. Probert, W. Clegg, J. A. G. Williams and V. N. Kozhevnikov, Dalton Trans., 2016, 45, 6949-6962.

36 B. Tong, H.-Y. Ku, I. J. Chen, Y. Chi, H.-C. Kao, C.-C. Yeh, C.-H. Chang, S.-H. Liu, G.-H. Lee and P.-T. Chou, J. Mater. Chem. C, 2015, 3, 3460-3471.

37 W. Wang, W. Meng and H. Du, Dalton Trans., 2016, 45, 59455948.

38 L. K. McKenzie, I. V. Sazanovich, E. Baggaley, M. Bonneau, V. Guerchais, J. A. G. Williams, J. A. Weinstein and H. E. Bryant, Chem.-Eur. J., 2017, 23, 234-238. 